\title{
The Relationship between Hierarchy Ambiguity and Emotional Cut off among a Sample of Married Female and Male Employees Working at Some Public Hospitals in Amman
}

\author{
Rasha Mohammed Yaqoub A. Al- Tamimi
}

Prof. Adel George Tannous

\begin{abstract}
the present study aimed to explore the relationship between hierarchy ambiguity and emotional cut off among a sample of married female and male employees working in 2 public hospitals in Amman, Jordan. It aimed to explore the levels of hierarchy ambiguity and emotional cut off in accordance with (the duration of the marriage, family income, and academic qualifications). The sample consists from 155 individuals (doctors and nurses) who work in the operation and ICU rooms in public hospitals. The researchers used two scales; the hierarchy ambiguity scale and the emotional cut off scale. It was found that the respondents' hierarchy ambiguity and emotional cut off levels are low. It was found that there isn't any statistically significant relationship between hierarchy ambiguity and emotional cut off. It was found that there isn't any statistically significant difference in the respondents' hierarchy ambiguity and emotional cut off which can be attributed to the family income and academic qualifications. That doesn't apply to marriage duration. For instance, it was found that there is a significant difference between the respondents' emotional cut off levels which can be attributed to the marriage duration for the favor of the ones who have been married for a period that exceeds 5 years. It was found that there isn't any statistically significant difference between the respondents' hierarchy ambiguity which can be attributed to the marriage duration.
\end{abstract}

Keywords: Hierarchy Ambiguity, Emotional Cut off, Public Hospitals

DOI: $10.7176 / \mathrm{JEP} / 10-36-20$

Publication date: December $31^{\text {st }} 2019$

\section{Introduction:}

Marriage plays a significant role in constituting society. It plays a significant role in meeting people's needs and enabling them to do the tasks assigned to them. Husbands and wives play a significant role in achieving economic development. Due to the industrial revolution, changes occurred to the roles of husbands and wives. For instance, such revolution turned many husbands and wives from farmers into civil employees. That threatens marriage and families. However, they will remain the way for reproduction (Fenell, 2012).

However, when conducting a comparison between families in the contemporary age and previous ages, it can be noticed that families during the contemporary age suffer from social and psychological problems.

Some conservative societies aimed at hiding such problems and reducing their severity (Al-Braithen, 2008).

Most people want to get married and keep being married without suffering from emotional problems or getting divorced. Many people want a marital relationship that involves fairness and equality. However, that doesn't mean that all the tasks must be divided equally between husband and wife. In fact, husband and wife must do the tasks assigned to them in a regular manner (Olson and Degrain, 2000).

The changes that occur to the family and individuals lead to the occurrence of marriage problems. Such problems, include: exerting effort by the wife to enjoy autonomy. Exerting such efforts may lead to experiencing a negative response by the husband (Nichols and Everret, 1986). Emotional cut off is considered the most important problem that may occur between husband and wife. It's different from a dispute that may occur between husband and wife. It negatively affects the marital relationship and leads to experiencing tension in this relationship. It may lead to experiencing emotional and psychological alienation, and dishonesty and losing mutual trust. It may lead to holding each one accountable for the problem. It may lead to divorce eventually (AlShwashreh and Abed Al-Rahman, 2018). 


\section{Hierarchy Ambiguity}

According to s (1986), family hierarchy ranges from individual-based system to marriage- based system, to father-based system to brotherhood system. All of those system represent jointly the complex family hierarchy.

The marriage-based hierarchy is represented in the way in which the husband respond and act. It's represented in the way the spouses make decisions related to the marital life. It's formed through the communication pattern between the spouses. That applies provided that the quality and time of expression differ. The conflict between the spouses is affected the identify conflict of the husband and the things he demand for. It's affected by the circumstances surrounding the spouses. In some extreme cases, the husband may turn a request into a question to avoid the expected rejection (Cross, 2001).

According to Haley, the hierarchy is existent in all human relationships, including in family relationships and marital relationships. Through family hierarchy, each person will be having an authority that has been granted to him or strived for obtaining it (Haley, 1977). This authority is connected to the decision making authority in the family. It's granted to individuals based on age and situational factors and capabilities-related factors (Al-Udwan and Al-Najar, 2016). Madanes (1981) suggest that all spouses strive for sharing everything equally and organize their hierarchal relationships. He suggests that all seek receiving assistance and protection. In the marital hierarchy, one of the spouses may be responsible for making family-related decisions and the other spouse makes decisions related to the external community. In the marital hierarchy, one of the spouses may be responsible for making decisions related to family and friends and the other spouse may be responsible for making financial decisions. The problems related to marital hierarchy can be solved through forming a strong relationship with (Haley, 1977), or through utilizing the illness symptoms of a spouse in the lower level of the hierarchy in a specific subject and letting him/her waive the authority. In this case the spouse who doesn't' have illness symptoms shall help the other in doing his/her tasks or deprive himself/herself from his/her rights. When the spouse possessing less authority show resistance or claim that the other spouse has less power, he/she shall become stronger than the other spouse (Madanes, 1981). That shall lead to experiencing hierarchy ambiguity and threatening the marital relationship. That shall lead to suffering from problems that are difficult to solve. The hierarchy ambiguity shall be manifested in the ambiguity of the one who shall take the decision or be influential in daily situations (Hecher\&Wetchler, 2003). Decisions are made by a spouse through being delegated by the other spouse (Rodman, 1972). Such problems may lead to having a spouse refraining from consulting the other in the decisions he/she made alone (Ramu, 1988). Such problems may lead to influencing the other spouse through using indirect methods. That can be done through consulting the other spouse without taking his/her opinion into consideration. After that, the spouse can claim that he/she took the opinion into consideration to order to avoid being held responsible for the decision made based on this opinion (Olson and Defrain, 2000). Spouse influence one another through using useful means. However, such use distracts the spouses from the main problems. That shall hinder them from addressing the existent program. It may lead to the emergence of new problems (Madanes, 1981). Therefore, strategic family therapy aims at addressing the hierarchy ambiguity in order to change the unhealthy behavior (Gladding, 2002).

The spouses who work in healthcare institutions show less marital satisfaction levels than others. That may be attributed to work conditions, such as: the long working hours or working in a shift system (Abdul Azeez\&Ghasidas, 2013). That may be attributed to home-related conditions, such as: the inadequacy of the time dedicated for meeting at home that should be a place for relaxing (Olson\&Defrain, 2003). Such inadequacy shall enforce pressure on spouses in terms of taking of care of children, housework, and being consumed thinking about expenditure and financial issues (Fenell, 2012). That shall make work affect home issue and vice versa. The longer the day at work is, the more disturbed the relationships in the house would be. The more the disturbed the day at the house, the spouse(s) will have more desire to work much to avoid thinking about that. In case both spouses are employees, it may lead to experiencing the phenomenon of (double income, no sex). In this phenomenon, the income of both spouses shall be doubled and the sexual relationship shall be practiced a little (Olson \&Defrain, 2003). Working for long hours may lead to affect the way in which the decisions are made by spouses. In case a spouse felt that there is unfairness in the way of making the decision, he/she may decide to make the decision making process equal. If both spouses took care of children, they shall feel that there is a balance the way of distributing roles (Dekker, 2007).

Under the equity theory, power in the marital hierarchy lies in the decision making authority. It assumes that individuals are driven by their desire to be treated equally in the relationship. One shall conduct a comparison between the extent of his/her contributions and the outcomes gained by others. When one realizes that the outcome he/she gained are less than the outcomes gained by his/her spouse in comparison to contributions, there shall be an atmosphere of tension. Such tension shall drive the spouse to reduce this level of tension (Webster \& 
Rice, 1996). The inequality-related thoughts are influenced by sexual expectations. The status of the spouse who benefit more and the status of the spouse who benefit less are affected by the marital disputes. It should be noted that marital distress and low marital satisfaction are strongly connected with benefitting less (Le Baron, 2014). Spouses seek enjoying equality in roles and responsibilities in order to settle conflicts. However, spouses must waive some rights and adjust the thoughts related to marital happiness in accordance with the surrounding situations. The unequal relationship creates a tensed atmosphere and increases the probabilities of experiencing depression (Deckers, 2007). The equity theory is an objective theory that is based on one's perceptions about the relationship. It interprets the transformations made to the decision making process due to the financial status of the spouses or the shift from one stage to another (Webster \& Rice, 1996).

The equivalence between spouses throughout the marital stages change. That's attributed to the acquisition of new characteristics by one or the family. Each marital stage requires meeting certain demands. Meeting such demands shall enable the family member to perform his/her functions. Seeking to meet the sexual role assigned by society shall reduce the capability of the spouse to do his/her functions (Smith \& Smith, 2006).

\section{Emotional cut off}

Any defect in the family relationships shall lead to experiencing psychological instability by the family members. Providing inadequate attention by the spouses to addressing this defect shall lead to the loss of respect and positive emotions. It may lead to experiencing emotional cut off. Emotional cut off leads to many disputes between the spouses. That shall threaten the survival of the marital relationship. It shall also reduce the emotional harmony between them ((Al-Shwashreh and Abed Al-Rahman, 2018).

Titleman (2003) Clarified that the emotional cutoff couldn't be occurred or continued in the presence of one individual; it is a process needs at least two individuals to feel emotionally cutoff.

Bowen (1978) adds that emotional cut off refers to a method that is used by individuals in order to alienate themselves from their families in order to reduce the emotional burden derived from problems.

Kerr (1988) suggests that emotional cut off refers to cutting off the relationship with the family due the feelings of distress. Such feelings result from emotional miscommunication. According to Weiss (1976), marriage problems may lead to experiencing distress by the spouse. Such distress is considered similar to the distress experienced by children who stopped being attached to their parent. It usually leads to the separation of adults (Weiss, 1976)

Emotional cut off is considered an extreme solution for reducing the anxiety resulting from close relationship to a family member causing tension. It is practiced through staying away from that family member or avoiding the tensed situations that involves interacting with him. It shall lead to the emergence of more problems (Sholevar\&Schwoeri, 1986).

Emotional cut off may be practiced intentionally in order to avoid major conflicts that cause tension. It may be practiced internally or physically. The signs indicating that emotional cut off is being experienced include: separation, isolation, withdrawal, loneliness, and denial for the significance of the relationship (titelmam, 2003).

There are factors leading to experiencing emotional cut off. Emotional cut off may be experienced after the passage of numerous years. It may be initiated by a spouse suddenly due to a conflict. That's because the latter spouse believes that the relationship should not continue after the occurrence of this dispute that. Emotional cut off may be initiated by both spouses (Gilbert, 2006).

The types of emotional cut off are (Titelman, 2003):

1- $\quad$ Primary emotional cut off: This emotional cut off is practiced when one cuts off his relationship with his/her parent(s)

2- $\quad$ Secondary emotional cut off: This emotional cut off is practiced when one cuts off his relationship with his/her brother(s), sister(s), aunt(s), uncle(s), and/or spouse

Bowen included four aspects to address the level of differentiation: emotional reactivity (ER), fusion with others (FO), the emotional cut off (EC), and the ability to take I-position. Spouses who has lower level of differentiate tend be more emotionally reactive and emotionally cutoff, because their feelings and thoughts are compound, on the other side, spouses who have a higher differentiation level capable of taking I-position comes from the clear feeling with the self (Kruze, 2007). 
In Bowen theory, differentiation is considered the most important factors. It's affected by psychological health and maturity. It affects marital disputes, emotional cut off and signs of failure to adapt among spouses. Internal differentiation manifests through separating ideas and emotions. That is done through achieving a balance between intimacy and autonomy. The couples with low level of differentiation can't be impartial. They also have low autonomy level (Titelman, 2003)

The second central key in Bowen theory is that both of the spouses represent their families, and develop the relationship when they're being more cognitively balanced, and works as a unit (Gladding, 2002).

Every Spouse holds the unresolved psychological issues with his/her family of origin to the marital relationship; so when one of the spouses feels emotionally cutoff, it will accompanied with an anxiety that creates negative behaviors to compensate this obstacle and reach the main goal which is the balance between individuality (the tendency to independency) and togetherness (the need to be belonged and acceptable, this balance creates the inner peace (Bazant, 2009).

Maggie Hayes (1979) studied the causes of divorce among spouses in middle age years indicated that the majority of the spouses with the husband dominant pattern impeded gaining an acceptable independency, and achieving progress at the academic and career wise. Moreover, in some cases, the husband-wife dominant pattern may increase the probability of the marital violence (Sholevar\&Scwoeri, 2003). Especially when it is related to a vocational chronic stress, the likelihood to engage in psychological and physical aggression is higher (Frye\&Kerney, 2006). and marital withdrawal following this heavy load times at work (Story\&Repetti, 2006).

Many societies suffer from emotional cut off, such as: Asian societies. In such societies, the emotional cut off is prevalent. That's attributed to the nature of the dominant culture (Sahebihagh, Khirshidi, Atri\&Jafarabadi, 2017). For instance, the culture may set many social determinants. Such determinants emphasize the significance of protecting families, sons and daughters. That leads to increasing the possibilities of experiencing emotional cut off. That's because people in such societies avoid getting divorced to avoid having negative attitudes towards them (Yeitzhak\& Peleg, 2011).

Walsh (2006) suggest that most of the divorce cases among the spouses who have been married for a period of (5-7) years. The divorce in such marriages is attributed to experiencing many irresolvable disputes. It's also attributed to experiencing emotional separation. Experiencing such separation shall make the spouse refrain from handling his/her responsibilities. Such refrainment shall lead to experiencing emotional cut off and using offensive expressions and expressions that involve criticism. In such a case, each spouse shall have his/her own personal life and start seeking divorce (Walsh, 2006).

Jafarizadeh and Afrasiabi (2015) aimed to explore the relationship between emotional divorce and personal factors in Behbahan. The simple random sampling method was used. The sample consists from 57 individuals. A survey was used for data collection. It was found that there is a significant relationship between emotional divorce and several personal factors, such as: sex, understanding spouse, spouse expectations, using nice words by spouse, using drugs and understanding spouse situations. It was found that there isn't a significant relationship between emotional divorce and several personal factors, such as: pessimism, occupational differences, misplaced expectations, educational differences, age and forced marriage.

Sahaf (2015) Aimed to explore the relationship between marital adjustment and family stability among a sample consisting from several married couples in Makkah. A questionnaire was used. The sample consists from (459) persons. Frequencies and percentages and Pearson correlation coefficient are calculated and t-test and analysis of variance test $(\mathrm{T})$ are conducted. It was found that there is a significant relationship between marital adjustment and family stability among couples in Makkah. Thus, marital adjustment shall affect family stability. It was found that there isn't any significant difference between the respondents' marital adjustment which can be attributed to age.

Kincaid and Caldwell (2008) aimed to explore the reasons leading to marital separation and the consequences resulting from it. They used a survey and collected data from 56 individuals. It was found that such reasons include: communication difficulties, lack of love and emotional abuse

It hasn't been proved that there are high levels of emotional cut off among nurses in Iranian cities (Sahebihagh, Khirshidi, Atri\&Jafarabadi, 2017). However, Elbarazy\&Loney\& Yousef \& Elias (2017) found that nurses suffer from high level of psychological burnout and emotional distress and low level of productivity. Such levels are attributed to the long working hours of nurses. The latter study was conducted in 7 Arab countries. 
Katyal (2017) conducted a study in India. He found that psychological exhaustion and burnout levels are higher among the nurses working at public hospitals. Thus, such nurses have higher probabilities to experience psychological problems. That applies especially to the nurses who work at the ICU room (Chaung et al., 2016).

Alshawashereh and Abdel Rahman (2017) aimed to explore the relationship between emotional separation and irrational thoughts among married people. The sample consists from 242 married individuals. Two scales were used. One of them measures irrational thoughts and the other scale measures emotional separation. It was found that there is a positive significant relationship between emotional separation and irrational thoughts among married people. Values of the correlation coefficient, frequencies and percentages were calculated.

The present study aimed to shed a light on several aspects of the lives of the married employees working at the operation and ICU rooms in some public hospitals in Amman. It's necessary to understand the factors related to that within an economic and developmental frameworks. Family experience several development stages. These stages are three ones (Fenell, 2012). During the first stage, the newly married couple face many challenges and must handle many responsibilities (Gladding, 2002). Such challenges are related to daily life issues and the spouses' relationships with their families (Minuchin, 1974). In case the spouses didn't adjust themselves to meet the new demands and couldn't settle the conflicts with their family members, there shall be high probabilities to experience emotional cut off and then actual divorce (Gladding, 2002).

There are many studies that shed a light on emotional cut off worldwide (Shehabihagh, 2017). However, as far as the researchers know, there aren't many studies that shed a light on emotional cut off in Jordan. In addition, there aren't many studies that shed a light on hierarchy ambiguity. That applies especially to the studies that target the employees who work in the medical institutions in general and the employees who work in the public hospitals in particular. Therefore, the present study aimed to explore the relationship between hierarchy ambiguity and emotional cut off among a sample of married female and male employees working in public hospitals in Amman, Jordan. It aimed to identify the levels of hierarchy ambiguity and emotional cut off in accordance with (the duration of the marriage, family income, and academic qualifications)

\section{The Study's Questions:}

The present study aimed to answer the following questions:

1- What's the level of hierarchy ambiguity among the married female and male employees working at public hospitals in Amman?

2- What's the level of emotional cut off among the married female and male employees working at public hospitals in Amman?

3- Is there any statistically significant relationship - at the statistical significance level of $(a=05)$ - between hierarchy ambiguity and emotional cut off among the married female and male employees working at public hospitals in Amman?

4- Is there any statistically significant difference - at the statistical significance level of $(a=05)$ - between the respondents' hierarchy ambiguity levels which can be attributed to (the duration of the marriage, family income, and academic)?

5- $\quad$ Is there any statistically significant difference - at the statistical significance level of $(\mathrm{a}=05)$ - between the respondents' emotional cut off levels which can be attributed to (the duration of the marriage, family income, and academic)?

\section{Methodology:}

\section{The Study's Design:}

The researchers adopted a descriptive approach. A correlative approach wad adopted. These approaches were adopted to explore the relationship between hierarchy ambiguity and emotional cut off among a sample of married female and male employees working in public hospitals in Amman, Jordan. They were adopted to explore the levels of hierarchy ambiguity and emotional cut off in accordance with (the duration of the marriage, family income, and academic qualifications) 


\section{Sample:}

Two public hospitals in Amman were sampled. One of them is located in East Amman, whereas the other is located in West Amman. The present study targeted the whole population. The population consists from all of the married female and male employees (doctors and nurses) working in the operation and ICU rooms in public hospitals in Amman. 160 questionnaire forms were distributed to the employees who work at these rooms. 5 forms were excluded due to missing data. Such missing data include demographic data and variables-related data. 155 forms were retrieved. The response rate is greater than $95 \%$. Thus, the data in 155 forms was analyzed.

Regarding the duration of the marriage, 84 respondents have been married for a duration that's less than 5 years. 71 respondents have been married for a duration that's more than 5 years. Regarding the family income, 116 respondents have family income that is less than 1000 JDs. 39 respondents have family income that is more than 1000 JDs. Regarding academic qualifications, 39 respondents have a diploma degree or less. 116 respondents have a BA degree or a higher degree. When distributing the questionnaire forms in hospitals, the researchers complied with ethics. The present study was conducted during (July- October) of 2019. The members of the sample volunteered to participate in the present study. They agreed to participate after illustrating the significance of their participation by the researchers. The researchers distributed the questionnaire forms to the sample during the break period. The members of the sample were informed that their participation in the study is very significant. Each member of the sample filled in the form in private and gave it back to the researchers. The process of filling the form took (15-20) minutes. After collecting data, it was analyzed statistically through using the SPSS program. The value of Pearson correlation coefficient was calculated to identify the correlation between the hierarchy ambiguity and emotional cut off. Means and standard deviations were calculated to explore the levels of hierarchy ambiguity and emotional cut off in accordance with (the duration of the marriage, family income, and academic qualifications). Table (1) presents the demographic characteristics of data.

Table (1): Percentages and frequencies of the study's variables

\begin{tabular}{|c|c|c|c|}
\hline & Categories & Frequencies & Percentages \\
\hline \multirow{2}{*}{ Duration of the marriage } & Less than 5 years & 84 & 54.2 \\
\hline & More than 5 years & 71 & 45.8 \\
\hline \multirow[t]{2}{*}{ Family income } & Less than 1000 JDs & 116 & 74.8 \\
\hline & More than $1000 \mathrm{JDs}$ & 39 & 25.2 \\
\hline \multirow[t]{2}{*}{$\begin{array}{l}\text { The academic } \\
\text { qualification of wife }\end{array}$} & $\begin{array}{l}\text { Diploma degree or a } \\
\text { lower degree }\end{array}$ & 39 & 25.2 \\
\hline & $\begin{array}{l}\text { BA degree or a higher } \\
\text { degree }\end{array}$ & 116 & 74.8 \\
\hline \multirow{3}{*}{$\begin{array}{l}\text { The academic } \\
\text { qualification of husband } \\
\text { of husband }\end{array}$} & $\begin{array}{l}\text { Diploma degree or a } \\
\text { lower degree }\end{array}$ & 47 & 30.3 \\
\hline & $\begin{array}{l}\text { BA degree or a higher } \\
\text { degree }\end{array}$ & 108 & 69.7 \\
\hline & Total & 155 & 100.0 \\
\hline
\end{tabular}

\section{Data analysis methods:}

To analyze the collected data, the researcher calculated percentages, frequencies, means and standard deviations. He also calculated the values of the correlation coefficient to explore the relationship between variables. The researcher adopted a descriptive analytical approach for analyzing data. This approach is usually adopted in scientific research for providing a sensory description for objects. It's adopted to determine whether the sensory attributes of objects are accepted or not. It's also adopted to understand and explore variables and their components (Lawless and Heymann, 1999). 


\section{Instruments}

\section{The study's instruments are identified below:}

The hierarchy ambiguity scale: A scale was developed for measuring the hierarchy ambiguity. It was developed after reviewing several scales, such as: the scale of the marital power, the scale for measuring the outcomes of such power (Le Baron \& Miller \&Yorgason, 2014), the marital decision scale (Madden, 2014), the decision making and interpersonal control scale (Mason and Smith, 2000). The hierarchy ambiguity scale aimed to measure two dimensions. The first one is the marital decision (12 items). The second dimension is marital influence (19 items /item No. 13 -item No. 31). A three-point Likert scale was adopted. It consists from the following scores: 0 score (i.e. unclear), 1 score (i.e. one of them) and 2 scores (i.e. both of them).

1- The marital decision dimension: It is connected to the one who makes the final decision in various aspects of life. It is represented in items No. $(2 \cdot 3 \cdot 4 \cdot 5 \cdot 6 \cdot 7 \cdot 8 \cdot 9 \cdot 10 \cdot 11 \cdot 12 \cdot 1)$. The scores of this dimension is within the range of $(0-12)$.

2- $\quad$ The marital influence dimension: It's one of the strength aspects in the marital hierarchy. It's represented in direct and indirect words and behaviors that the spouse uses in order to change the other spouse. It is represented in items No $13-31$. The scores of this dimension is within the range of $(0-19)$.

\section{The total scores are within the range of $0-31$.}

\section{The maximum limit is 1 score and the minimum limit is $\mathbf{0}$ score.}

The total score of the hierarchy ambiguity that is within the range of 0-33 is low. The total score of the hierarchy ambiguity that is within the range of 43-67 is moderate. The total score of the hierarchy ambiguity that is within the range of 68-100 is high.

The emotional cut off scale: This scale was developed to meet the study's goals. It consists from 30 items. It was developed after reviewing the relevant studies (Skowron\& Friedlander, 1998) and the emotional separation ((AlShwashreh and Abed Al-Rahman, 2017).

Statistical criteria for the emotional cut off scale.

The emotional cut off scale adopted the five point Likert scale. The latter scale consists from the following categories; strongly agree, agree, neutral, disagree, and strongly disagree. These categories represent the following scores respectively; 5, 4, 3, 2 and 1 .

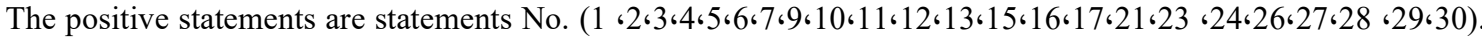
The negative statements are statements No. $(14$ ، 18 ،19،2022،25).

The total score of the emotional cut off that is within the range of 1-2.33 is low.

The total score of the emotional cut off that is within the range of 2.34-3.67 is moderate.

The total score of the emotional cut off that is within the range of 3.68-5 is high.

These statistical criteria were set through the following method:

(The maximum limit (5)/ the minimum limit (1))/ The number of categories (3)

$(5 / 1) / 3=1.33$

Thus, the interval is 1.33

The study's procedures:

Ethical consent:

The consent of the institutional review Board (IRB) at Jordan University Hospital was obtained. The consent of the institutional review Board (IRB) at the Jordanian Ministry of Health was obtained. These consents were obtained in order to collect data from the employees who work at the aforementioned hospitals

Pilot study 
Emotional cut off

Measuring validity through experts: The emotional cut off scale was passed to ten (10) university professors who were selected from the University of Jordan. They were also selected from other public and private Jordanian universities. They are specialized in counselling, including family counselling. They were asked to provide their opinions about the relevancy of each item to the study's goals. They were asked to provide their opinions about language, and clarity of items. They were asked to make deletions, additions, and changes. The researchers decided to keep the items that are approved by $80 \%$ of the experts. The sample percent applies to the adjustment of statements. Nine statements were deleted based on the experts' opinions. These items are items No. (10،22 ، 27 ، 31 ، $32 \cdot 33 \cdot 35 \cdot 39)$. Thus, the final version of the scale consists from 30 items.

The discriminant functions of each item

In order to measure the structural validity of the scale, the values of the correlation coefficient were calculated. That was done after retrieving the questionnaire forms from an exploratory sample. The exploratory sample consists from 30 married female and male employees working in public hospitals. However, the members of the exploratory sample are different from the members of the actual sample. The values of the correlation coefficient represent validity. They are within the range of $0.86-0.34$. The table listed below displays these values:

Table (2): The values of the correlation coefficient between the items and the total score

\begin{tabular}{|l|l|l|l|l|l|}
\hline Statement No. & $\begin{array}{l}\text { Correlation } \\
\text { coefficient }\end{array}$ & Statement No. & $\begin{array}{l}\text { Correlation } \\
\text { coefficient }\end{array}$ & Statement No. & $\begin{array}{l}\text { Correlation } \\
\text { coefficient }\end{array}$ \\
\hline 1 & 0.57 & 11 & 0.83 & 21 & 0.64 \\
\hline 2 & 0.39 & 12 & 0.66 & 22 & 0.73 \\
\hline 3 & 0.79 & 13 & 0.86 & 23 & 0.69 \\
\hline 4 & 0.82 & 14 & 0.76 & 24 & 0.50 \\
\hline 5 & 0.84 & 15 & 0.57 & 25 & 0.75 \\
\hline 6 & 0.81 & 16 & 0.34 & 26 & 0.76 \\
\hline 7 & 0.53 & 17 & 0.57 & 27 & 0.59 \\
\hline 8 & 0.54 & 18 & 0.70 & 28 & 0.64 \\
\hline 9 & 0.55 & 19 & 0.60 & 29 & 0.58 \\
\hline 10 & 0.77 & 20 & 0.71 & 30 & 0.80 \\
\hline
\end{tabular}

All of the values of the correlation coefficient are accepted. They are greater than 0.30 . Therefore, none of those statements was deleted.

Reliability of the emotional cut off scale:

In order to measure the reliability of the emotional cut off scale, the total value of the internal consistency coefficient (i.e. Cronbach Alpha coefficient) was calculated. That was done after retrieving the questionnaire forms from an exploratory sample. The exploratory sample consists from 30 married female and male employees working in public hospitals. However, the members of the exploratory sample are different from the members of the actual sample. The total value of the Cronbach Alpha coefficient is 0.95. The values of the Cronbach Alpha coefficient enable the researchers to meet the study's goals.

The hierarchy ambiguity scale:

Validity of the scale was measured through two methods:

Measuring validity through experts: The hierarchy ambiguity scale was passed to ten (10) university professors who were selected from the University of Jordan. They were also selected from other public and private Jordanian universities. They are specialized in counselling, including family counselling. They were asked to provide their opinions about the relevancy of each item to the study's goals. They were asked to provide their opinions about language, and clarity of items. They were asked to make deletions, additions, and changes. The researchers decided to keep the items that are approved by $80 \%$ of the experts. The sample percent applies to the adjustment of statements. Nine statements were deleted based on the experts' opinions.

Three statements were deleted based on the experts' views. These statements are: statements No. 27, 26, and 38. Thus, the final version of the scale consists from 35 . 
The discriminant functions of each item

In order to measure the structural validity of the scale, the values of the correlation coefficient were calculated. That was done after retrieving the questionnaire forms from an exploratory sample. The exploratory sample consists from 30 married female and male employees working in public hospitals. However, the members of the exploratory sample are different from the members of the actual sample. The values of the correlation coefficient represent validity. They are within the range of $0.75-0.12$. The table listed below displays these values:

Table (3): The values of the correlation coefficient between the items and the total score

\begin{tabular}{|l|l|l|l|l|l|l|l|l|}
\hline $\begin{array}{l}\text { Statemen } \\
\mathrm{t} \text { No. }\end{array}$ & $\begin{array}{l}\text { Correlatio } \\
\mathrm{n} \\
\text { coefficien } \\
\mathrm{t} \text { with the } \\
\text { area }\end{array}$ & $\begin{array}{l}\text { Correlatio } \\
\mathrm{n} \\
\text { coefficien } \\
\mathrm{t} \text { with the } \\
\text { instrumen } \\
\mathrm{t}\end{array}$ & $\begin{array}{l}\text { Statemen } \\
\mathrm{t} \text { No. }\end{array}$ & $\begin{array}{l}\text { Correlatio } \\
\mathrm{n} \\
\text { coefficien } \\
\mathrm{t} \text { with the } \\
\text { area }\end{array}$ & $\begin{array}{l}\text { Correlatio } \\
\mathrm{n} \\
\text { coefficien } \\
\mathrm{t} \text { with the } \\
\text { instrumen } \\
\mathrm{t}\end{array}$ & $\begin{array}{l}\text { Statemen } \\
\mathrm{t} \text { No. }\end{array}$ & $\begin{array}{l}\text { Correlatio } \\
\mathrm{n} \\
\text { coefficien } \\
\text { with the } \\
\text { area }\end{array}$ & $\begin{array}{l}\text { Correlatio } \\
\mathrm{n} \\
\text { coefficien } \\
\mathrm{t} \text { with } \\
\text { instrumen } \\
\mathrm{t}\end{array}$ \\
\hline 1 & 0.44 & 0.09 & 13 & 0.52 & 0.52 & 25 & 0.45 & 0.50 \\
\hline 2 & 0.47 & 0.14 & 14 & 0.43 & 0.40 & 26 & 0.76 & 0.64 \\
\hline 3 & 0.64 & 0.37 & 15 & 0.41 & 0.44 & 27 & 0.38 & 0.46 \\
\hline 4 & 0.54 & 0.34 & 16 & 0.38 & 0.40 & 28 & 0.61 & 0.72 \\
\hline 5 & 0.39 & 0.36 & 17 & 0.36 & 0.56 & 29 & 0.62 & 0.43 \\
\hline 6 & 0.15 & -0.12 & 18 & 0.55 & 0.34 & 30 & 0.60 & 0.50 \\
\hline 7 & 0.38 & 0.28 & 19 & 0.60 & 0.32 & 31 & 0.73 & 0.62 \\
\hline 8 & 0.72 & 0.51 & 20 & 0.58 & 0.50 & 32 & 0.72 & 0.55 \\
\hline 9 & 0.38 & 0.36 & 21 & 0.44 & 0.34 & 33 & 0.64 & 0.47 \\
\hline 10 & 0.54 & 0.40 & 22 & 0.08 & 0.27 & 34 & 0.52 & 0.58 \\
\hline 12 & 0.55 & 0.37 & 23 & 0.79 & 0.75 & 35 & 0.58 & 0.37 \\
\hline
\end{tabular}

$(*)$ This sign means that the value is statistically significant at the statistical significance level of $(a=0.05)$

$(* *)$ This sign means that the value is statistically significant at the statistical significance level of $(a=0.01)$

All the correlation coefficient values are accepted. They are greater than 0.30, except for statements No. 2, 6 and 12. Thus, these statements were deleted.

Reliability of the hierarchy ambiguity scale

In order to measure the reliability of the emotional cut off scale, the values of the internal consistency coefficient (i.e. Cronbach Alpha coefficient) were calculated. That was done after retrieving the questionnaire forms from an exploratory sample. The exploratory sample consists from 30 married female and male employees working in public hospitals. However, the members of the exploratory sample are different from the members of the actual sample. The values of the Cronbach Alpha coefficient are displayed below 
Table (4): The values of the Cronbach Alpha coefficient

\begin{tabular}{|l|l|}
\hline Area & Internal consistency \\
\hline After taking the decision & 0.83 \\
\hline After experiencing the marital influence & 0.91 \\
\hline Total & 0.91 \\
\hline
\end{tabular}

The present study aimed mainly to explore the relationship between hierarchy ambiguity and emotional cut off among a sample of married female and male employees working at public hospitals in Amman. The first and second questions are answered through calculating means and standard deviations. The third question is answered through calculating the values of Pearson correlation coefficient. The fourth question is answered through conducting the three way analysis of variance

The study's first question: What's the level of hierarchy ambiguity among the married female and male employees working at public hospitals in Amman?

To answer this question, means and standard deviations were calculated. The table below illustrates these values

Table (5): means and standard deviations for identifying the level of hierarchy ambiguity among the married female and male employees working at public hospitals in Amman

\begin{tabular}{|l|l|l|l|l|l|l|l|l|}
\hline Rank & No. & Area & Mean & Std. & $\begin{array}{l}\text { Percentage } \\
\text { of the } \\
\text { hierarchy } \\
\text { clarity }\end{array}$ & $\begin{array}{l}\text { Level of } \\
\text { the } \\
\text { hierarchy } \\
\text { clarity }\end{array}$ & $\begin{array}{l}\text { Percentage } \\
\text { of } \\
\text { hierarchy } \\
\text { the } \\
\text { ambiguity }\end{array}$ & $\begin{array}{l}\text { Level of } \\
\text { the } \\
\text { hierarchy } \\
\text { ambiguity }\end{array}$ \\
\hline & 1 & $\begin{array}{l}\text { Taking the marital } \\
\text { decision }\end{array}$ & 11.61 & .742 & 96.7 & High & 3.3 & Low \\
\hline & 2 & Marital influence & 14.28 & 4.471 & 75.1 & High & 24.9 & Low \\
\hline & Hierarchy & 25.89 & 4.599 & 83.2 & High & 16.8 & Low \\
\hline
\end{tabular}

Table (5) shows that taking the marital decision is ranked first due to showing a percentage of 96.7. The marital influence is ranked second due to showing a percentage of 75.1. The total percentage of hierarchy clarity is 83.2. The percentage of the hierarchy ambiguity of taking the marital decision is 3.3. The percentage of the hierarchy ambiguity of marital influence is 24.9 . The total percentage of the hierarchy ambiguity is 16.8 . All of the latter decisions is low.

The study's second question:

What's the level of emotional cut off among the married female and male employees working at public hospitals in Amman?

To answer this question, means and standard deviations were calculated. The table below illustrates these values

Table (6): means and standard deviations for identifying the level of emotional cut off among the married female and male employees working at public hospitals in Amman

\begin{tabular}{|l|l|l|l|l|}
\hline No. & Statement & Mean & Std. & Level \\
\hline 1. & I have difficulty in expressing my feelings to my spouse & 2.24 & 1.405 & Low \\
\hline 2. & $\begin{array}{l}\text { I feel distress when my spouse is near me } \\
\text { I believe that my spouse requests me to meet demands that } \\
\text { he/she doesn't deserve }\end{array}$ & 1.88 & 1.064 & Low \\
\hline 3. & I am not happy in my marital life & 1.59 & 1.037 & Low \\
\hline 4. & & & Low \\
\hline
\end{tabular}




\begin{tabular}{|c|c|c|c|c|}
\hline 5. & I feel that my marital life is boring & 1.70 & 1.119 & Low \\
\hline 6. & $\begin{array}{l}\text { Although there is a great emotional gap between me and my } \\
\text { spouse, I think that I am forced to keep this marriage going on }\end{array}$ & 1.55 & 1.129 & Low \\
\hline 7. & I feel annoyed from having sex & 1.54 & 1.027 & Low \\
\hline 8. & I experience marital jealousy & 2.60 & 1.510 & Moderate \\
\hline 9. & I experience alienation in marital life & 1.83 & 1.210 & Low \\
\hline 10. & I feel that my marital life is based on complaints, and disrespect & 1.57 & 1.025 & Low \\
\hline 11. & I avoid spending time with my spouse & 1.53 & 1.034 & Low \\
\hline 12. & When I face much pressure, I resort to my family not my spouse & 1.74 & 1.161 & Low \\
\hline 13. & $\begin{array}{l}\text { I avoid talking with my spouse about our daily problems. That's } \\
\text { because having such a conversation shall make things worse }\end{array}$ & 2.19 & 1.489 & Low \\
\hline 14. & I congratulate my spouse in events & 2.14 & 1.442 & Low \\
\hline 15. & I use various methods to avoid having sex with my spouse & 1.52 & 1.107 & Low \\
\hline 16. & $\begin{array}{l}\text { I sleep in a room that is different from the room that my spouse } \\
\text { sleeps at }\end{array}$ & 1.48 & 1.077 & Low \\
\hline 17. & I usually get into a disputes with my spouse on silly things & 2.17 & 1.318 & Low \\
\hline 18. & $\begin{array}{l}\text { My spouse and I use lovely and kind expressions when talking } \\
\text { with each other }\end{array}$ & 2.20 & 1.276 & Low \\
\hline 19. & $\begin{array}{l}\text { When my spouse gets home, I welcome him/her in a lovely } \\
\text { manner }\end{array}$ & 2.15 & 1.249 & Low \\
\hline 20. & We celebrate our wedding anniversary each year & 2.29 & 1.507 & Low \\
\hline 21. & I avoid attending events with my spouse & 1.83 & 1.280 & Low \\
\hline 22. & I always buy a gift for my spouse when I get a financial reward & 2.41 & 1.445 & Moderate \\
\hline 23. & $\begin{array}{l}\text { I have life values that are different from the counterpart values } \\
\text { of my spouse }\end{array}$ & 2.23 & 1.308 & Low \\
\hline 24. & $\begin{array}{l}\text { My ambitions and goals do not fit with the that ambitions and } \\
\text { goals of my spouse }\end{array}$ & 2.21 & 1.400 & Low \\
\hline 25. & $\begin{array}{l}\text { I find that my spouse has the characteristics of the one I } \\
\text { dreamed about }\end{array}$ & 2.41 & 1.385 & Moderate \\
\hline 26. & I regret getting married & 1.55 & 1.169 & Low \\
\hline 27. & I think much about getting & 1.51 & 1.130 & Low \\
\hline 28. & $\begin{array}{l}\text { If I don't have kids, my marital relationship would have } \\
\text { continued till today }\end{array}$ & 1.60 & 1.225 & Low \\
\hline 29. & Having sex is just a routine & 1.70 & 1.256 & Low \\
\hline 30. & $\begin{array}{l}\text { I believe that my spouse isn't handling his marital } \\
\text { responsibilities as he/she should be }\end{array}$ & 1.81 & 1.293 & Low \\
\hline 31. & Emotional cut off & 1.89 & .757 & Low \\
\hline
\end{tabular}

Based on table (6), the means of emotional cut off are within the range of 1.81-2.60. Statement 8 is ranked first, because its mean is 2.60. It states the following: (I experience marital jealousy). Statement No. 29 is ranked last, because its mean is 1.81. It states the following: (I believe that my spouse isn't handling his marital responsibilities as he/she should be). As for the total mean, it is 1.89 .

That means that the married female and male employees working at operation and ICU rooms in public hospitals show a poor emotional cut off level. 
The Study's Third Question:

Q.3: Is there any statistically significant relationship - at the statistical significance level of ( $a=05)$ - between hierarchy ambiguity and emotional cut off among the married female and male employees working at public hospitals in Amman?

The values of Pearson correlation coefficient are calculated to answer this question. Table (7) displays the values of Pearson correlation coefficient to identify the relationship between hierarchy ambiguity and emotional cut off among the married female and male employees working at public hospitals in Amman

Table (7): The values of Pearson correlation coefficient to identify the relationship between hierarchy ambiguity and emotional cut off among the married female and male employees working at public hospitals in Amman

\begin{tabular}{|c|c|c|}
\hline & & Emotional cut off \\
\hline \multirow[t]{3}{*}{ Taking the marital decision } & correlation coefficient value & $-.246(* *)$ \\
\hline & Sig, & .002 \\
\hline & Frequency & 155 \\
\hline \multirow[t]{3}{*}{ Marital influence } & correlation coefficient value & $.199(*)$ \\
\hline & Sig, & .013 \\
\hline & Frequency & 155 \\
\hline \multirow[t]{3}{*}{ Hierarchy } & correlation coefficient value & .153 \\
\hline & Sig, & .057 \\
\hline & Frequency & 155 \\
\hline
\end{tabular}

$(*)$ This sign means that the value is statistically significant at the statistical significance level of $(a=0.05)$

$(* *)$ This sign means that the value is statistically significant at the statistical significance level of $(a=0.01)$

Through table (7), it was found that there is a positive statistically significant relationship between emotional cut off from one hand and taking the marital decision and the marital influence from another hand. That was concluded among the married female and male employees working at public hospitals in Amman. It was found that there isn't any statistically significant relationship between hierarchy ambiguity and emotional cut off among the married female and male employees working at public hospitals in Amman.

The study's fourth question:

Is there any statistically significant difference - at the statistical significance level of $(\mathrm{a}=05)$ - between the respondents' hierarchy ambiguity levels which can be attributed to (the duration of the marriage, family income, and academic)?

Means and standard deviations are calculated to explore the levels of hierarchy ambiguity in accordance with (the duration of the marriage, family income, and academic qualifications). Table (8) shows these values below 
Table (8): Means and standard deviations explore the levels of hierarchy ambiguity in accordance with the duration of the marriage, family income, and academic qualifications

\begin{tabular}{|c|c|c|c|c|c|}
\hline & & & $\begin{array}{l}\text { Taking the } \\
\text { marital decision }\end{array}$ & $\begin{array}{l}\text { Marital } \\
\text { influence }\end{array}$ & Hierarchy \\
\hline \multirow{4}{*}{$\begin{array}{l}\text { Duration of the } \\
\text { marriage }\end{array}$} & \multirow{2}{*}{$\begin{array}{lll}\text { Less than } 5 \\
\text { years }\end{array}$} & Mean & 11.68 & 14.74 & 26.42 \\
\hline & & Mean & .604 & 3.887 & 4.046 \\
\hline & \multirow{2}{*}{$\begin{array}{l}\text { More than } 5 \\
\text { years }\end{array}$} & Mean & 11.54 & 13.73 & 25.27 \\
\hline & & Mean & .876 & 5.051 & 5.138 \\
\hline \multirow[t]{4}{*}{ Family income } & \multirow{2}{*}{$\begin{array}{l}\text { Less than } 1000 \\
\text { JDs }\end{array}$} & Mean & 11.67 & 14.49 & 26.16 \\
\hline & & Mean & .615 & 4.673 & 4.771 \\
\hline & \multirow{2}{*}{$\begin{array}{l}\text { More than } 1000 \\
\text { JDs }\end{array}$} & Mean & 11.44 & 13.64 & 25.08 \\
\hline & & Mean & 1.021 & 3.794 & 3.989 \\
\hline \multirow{4}{*}{$\begin{array}{l}\text { The academic } \\
\text { qualification of } \\
\text { wife }\end{array}$} & \multirow{2}{*}{$\begin{array}{ll}\text { Diploma } & \text { degree } \\
\text { or a } & \text { lower } \\
\text { degree } & \end{array}$} & Mean & 11.74 & 15.41 & 27.15 \\
\hline & & Mean & .498 & 4.070 & 4.062 \\
\hline & \multirow{2}{*}{$\begin{array}{l}\text { BA degree or a } \\
\text { higher degree }\end{array}$} & Mean & 11.57 & 13.90 & 25.47 \\
\hline & & Mean & .805 & 4.552 & 4.706 \\
\hline \multirow{4}{*}{$\begin{array}{l}\text { The academic } \\
\text { qualification of } \\
\text { husband }\end{array}$} & \multirow{2}{*}{$\begin{array}{ll}\text { Diploma } & \text { degree } \\
\text { or a } & \text { lower } \\
\text { degree } & \end{array}$} & Mean & 11.60 & 14.74 & 26.34 \\
\hline & & Mean & .712 & 4.326 & 4.439 \\
\hline & \multirow{2}{*}{$\begin{array}{l}\text { BA degree or a } \\
\text { higher degree }\end{array}$} & Mean & 11.62 & 14.07 & 25.69 \\
\hline & & Mean & .758 & 4.538 & 4.673 \\
\hline
\end{tabular}

Based on the table (8), it appears that there are difference between the respondents' hierarchy ambiguity level which can be attributed to (the duration of the marriage, family income, and academic qualifications)

To identify the statistical significance of those differences, the three way analysis of variance was conducted. The results of the latter analysis are presented in table (9) below 
Table (9): The results of the three-way analysis of variance to explore the statistical significance of the differences between the respondents' hierarchy ambiguity levels in accordance with (the duration of the marriage, family income, and academic qualifications)

\begin{tabular}{|c|c|c|c|c|c|c|}
\hline $\begin{array}{ll}\begin{array}{l}\text { Source } \\
\text { variance }\end{array} & \text { of }\end{array}$ & Area & $\begin{array}{l}\text { Sum of } \\
\text { squares }\end{array}$ & $\mathrm{df}$ & $\begin{array}{l}\text { Mean } \\
\text { squares }\end{array}$ & $F$ value & Sig. \\
\hline \multirow[t]{3}{*}{$\begin{array}{l}\text { Duration of } \\
\text { the marriage }\end{array}$} & $\begin{array}{l}\text { Taking the } \\
\text { marital } \\
\text { decision }\end{array}$ & .762 & 1 & .762 & 1.404 & .238 \\
\hline & $\begin{array}{l}\text { Marital } \\
\text { influence }\end{array}$ & 45.346 & 1 & 45.346 & 2.297 & .132 \\
\hline & Hierarchy & 57.868 & 1 & 57.868 & 2.798 & .096 \\
\hline \multirow[t]{3}{*}{$\begin{array}{l}\text { Family } \\
\text { income }\end{array}$} & $\begin{array}{ll}\text { Taking } & \text { the } \\
\text { marital } & \\
\text { decision } & \end{array}$ & 1.192 & 1 & 1.192 & 2.196 & .140 \\
\hline & $\begin{array}{l}\text { Marital } \\
\text { influence }\end{array}$ & 5.318 & 1 & 5.318 & .269 & .604 \\
\hline & Hierarchy & 11.546 & 1 & 11.546 & .558 & .456 \\
\hline \multirow[t]{3}{*}{$\begin{array}{l}\text { The academic } \\
\text { qualification } \\
\text { of wife }\end{array}$} & $\begin{array}{l}\text { Taking the } \\
\text { marital } \\
\text { decision }\end{array}$ & .811 & 1 & .811 & 1.493 & .224 \\
\hline & $\begin{array}{l}\text { Marital } \\
\text { influence }\end{array}$ & 45.210 & 1 & 45.210 & 2.291 & .132 \\
\hline & Hierarchy & 58.131 & 1 & 58.131 & 2.810 & .096 \\
\hline \multirow[t]{3}{*}{$\begin{array}{l}\text { The academic } \\
\text { qualification } \\
\text { of husband }\end{array}$} & $\begin{array}{ll}\text { Taking } & \text { the } \\
\text { marital } & \\
\text { decision } & \end{array}$ & .432 & 1 & .432 & .796 & .374 \\
\hline & $\begin{array}{l}\text { Marital } \\
\text { influence }\end{array}$ & .195 & 1 & .195 & .010 & .921 \\
\hline & Hierarchy & .047 & 1 & .047 & .002 & .962 \\
\hline \multirow[t]{3}{*}{ Error } & $\begin{array}{ll}\text { Taking } & \text { the } \\
\text { marital } & \\
\text { decision } & \end{array}$ & 81.458 & 150 & .543 & & \\
\hline & $\begin{array}{l}\text { Marital } \\
\text { influence }\end{array}$ & 2960.609 & 150 & 19.737 & & \\
\hline & Hierarchy & 3102.721 & 150 & 20.685 & & \\
\hline \multirow[t]{3}{*}{ Total } & $\begin{array}{ll}\text { Taking } & \text { the } \\
\text { marital } & \\
\text { decision } & \end{array}$ & 84.774 & 154 & & & \\
\hline & $\begin{array}{l}\text { Marital } \\
\text { influence }\end{array}$ & 3079.071 & 154 & & & \\
\hline & Hierarchy & 3257.135 & 154 & & & \\
\hline
\end{tabular}

Through table (9), it was found that 
It was found that there isn't any statistically significant difference- at the statistical significance level of $(\mathrm{a}=05)$ - between the respondents' hierarchy ambiguity levels which can be attributed to the duration of the marriage. That applies to all the areas jointly and separately.

- $\quad$ It was found that there isn't any statistically significant difference- at the statistical significance level of $(\mathrm{a}=05)$ - between the respondents' hierarchy ambiguity levels which can be attributed to the family income. That applies to all the areas jointly and separately.

- It was found that there isn't any statistically significant difference- at the statistical significance level of $(\mathrm{a}=05)$ - between the respondents' hierarchy ambiguity levels which can be attributed to the academic qualification of wife.. That applies to all the areas jointly and separately.

- It was found that there isn't any statistically significant difference- at the statistical significance level of $(\mathrm{a}=05)$ - between the respondents' hierarchy ambiguity levels which can be attributed to the academic qualification of husband. That applies to all the areas jointly and separately.

\section{The study's fifth question:}

Is there any statistically significant difference - at the statistical significance level of $(\mathrm{a}=05)$ - between the respondents' emotional cut off levels which can be attributed to (the duration of the marriage, family income, and academic)?

Means and standard deviations are calculated to explore the levels of emotional cut off in accordance with (the duration of the marriage, family income, and academic qualifications). Table (10) shows these values below

Table (10): Means and standard deviations explore the levels of emotional cut off in accordance with the duration of the marriage, family income, and academic qualifications

\begin{tabular}{|l|l|l|l|l|}
\hline & & Mean & Std. & Frequency \\
\hline $\begin{array}{l}\text { Duration of the } \\
\text { marriage }\end{array}$ & Less than 5 years & 1.77 & .659 & 84 \\
\cline { 2 - 5 } & More than 5 years & 2.04 & .840 & 71 \\
\hline Family income & Less than 1000 JDs & 1.92 & .692 & 116 \\
\cline { 2 - 5 } More than 1000 JDs & 1.80 & .927 & 39 \\
\hline $\begin{array}{l}\text { The of } \\
\text { qualification } \\
\text { husband }\end{array}$ & $\begin{array}{l}\text { Diploma degree or a } \\
\text { lower degree }\end{array}$ & 1.84 & .618 & 39 \\
\cline { 2 - 5 } & $\begin{array}{l}\text { BA degree or a } \\
\text { higher degree }\end{array}$ & 1.91 & .800 & 116 \\
\hline $\begin{array}{l}\text { The } \\
\text { qualification } \\
\text { husband of wife }\end{array}$ & $\begin{array}{l}\text { Diploma degree or a } \\
\text { lower degree }\end{array}$ & 1.91 & .728 & 47 \\
\cline { 2 - 5 } & $\begin{array}{l}\text { BA degree or a } \\
\text { higher degree }\end{array}$ & 1.88 & .772 & 108 \\
\hline
\end{tabular}

Based on the table (10), it appears that there are difference between the respondents' emotional cut off levels which can be attributed to (the duration of the marriage, family income, and academic qualifications)

To identify the statistical significance of those differences, the three way analysis of variance was conducted. The results of the latter analysis are presented in table (11) below 
Table (11): The results of the three-way analysis of variance to explore the statistical significance of the differences between the respondents' emotional cut off levels in accordance with (the duration of the marriage, family income, and academic qualifications)

\begin{tabular}{|l|l|l|l|l|l|}
\hline $\begin{array}{l}\text { Source of } \\
\text { variance }\end{array}$ & $\begin{array}{l}\text { Sum of } \\
\text { squares }\end{array}$ & $\mathrm{df}$ & $\begin{array}{l}\text { Mean of } \\
\text { squares }\end{array}$ & F value & Sig. \\
\hline $\begin{array}{l}\text { Duration of } \\
\text { the marriage }\end{array}$ & 2.827 & 1 & 2.827 & 5.016 & .027 \\
\hline $\begin{array}{l}\text { Family } \\
\text { income }\end{array}$ & .590 & 1 & .590 & 1.047 & .308 \\
\hline $\begin{array}{l}\text { The academic } \\
\text { qualification } \\
\text { of wife }\end{array}$ & .437 & 1 & .437 & .775 & .380 \\
\hline $\begin{array}{l}\text { The academic } \\
\text { qualification } \\
\text { of husband }\end{array}$ & .039 & 1 & .039 & .070 & .792 \\
\hline Error & 84.553 & 150 & .564 & & \\
\hline Total & 88.165 & 154 & & & \\
\hline
\end{tabular}

Based on table (11),

- $\quad$ It was found that there are statistically significant differences- at the statistical significance level of $(a=05)$ - between the respondents' emotional cut off levels which can be attributed to the duration of the marriage. The $\mathrm{F}$ value is 5.016. The significance value is 0.027 . The latter differences are for the favor of the ones who have been married for a period that exceeds 5 years.

It was found that there isn't any statistically significant difference- at the statistical significance level of $(\mathrm{a}=05)$ - between the respondents' emotional cut off levels which can be attributed to the family income. The $\mathrm{F}$ value is 1.047 . The significance value is 0.308

- $\quad$ It was found that there isn't any statistically significant difference- at the statistical significance level of $(\mathrm{a}=05)$ - between the respondents' emotional cut off levels which can be attributed to the academic qualification of wife. The $\mathrm{F}$ value is 0.775 . The significance value is 0.380

- $\quad$ It was found that there isn't any statistically significant difference- at the statistical significance level of $(\mathrm{a}=05)$ - between the respondents' emotional cut off levels which can be attributed to the husband. The $\mathrm{F}$ value is 0.070 . The significance value is 0.792 .

\section{Discussion:}

The present study aimed mainly to explore the relationship between hierarchy ambiguity and emotional cut off among a sample of married female and male employees working in the operation and ICU rooms in public hospitals in Amman. The latter employees include doctors and nurses. Through the study's first question, the researchers aimed to identify the hierarchy ambiguity level of respondents. It was found that hierarchy ambiguity level of respondents is low. The latter result may be attributed to the fact that many respondents have BA degree or a higher degree $(74.8 \%$ and $69.7 \%)$. Having such education shall enable respondents to take, and discuss decisions. Education plays a significant role in differentiation. The latter result is attributed to the fact that most of the respondents' family income is 1000 JDs or less (74.8\%). High salaries and disrespect are not associated with the professions that requires dedicating much time leading the employee to delegate their spouses and then experiencing hierarchy ambiguity. Thus, the ones who work in high salary jobs shall not delegate their spouses to take decisions for a long period of time. That is consistent with what's suggested by Al-Udwan and Al-Najar (2016). The latter researchers suggest that hierarchical power is affected by several factors related to situations and capabilities of individuals. The ones who work in tiring and low income jobs experience difficulties in using 
methods to influence the decision making process performed by their spouses. That's because using such methods shall lead to experiencing more problems and exerting much effort. The clarity in terms of using the marital influence strategies is represented in a percentage of 75.1. Having university degrees shall make both spouses exert much effort to achieve fairness in terms of role and responsibilities. They seek achieving that in a manner that satisfies both spouses. They seek achieving based on fixed and clear foundations without using influence strategies that may indirectly weaken the marital relationship. In fact, spouses seek achieving such fairness through using indirect influence strategies. Such strategies shall make both spouses experience marital happiness and satisfaction (Olson \&Defrain, 2003).

In addition that one of the most important reasons of hierarchy ambiguity is the ambiguity of the gender role criteria; the Jordanian society is a compenation of congruent nationalities which give the man clearly the right to take the final decisions.

Regarding the second question, it aims to shed al light on the level of emotional cut off among the married female and male employees working at public hospitals. It was found that the latter level is low. That may be attributed to the fact that the Jordanian society adopts eastern traditions. Such traditions hinder people from expressing emotional cut off-related issues. The same applies to many Asian countries. In such countries, talking about emotional cut off as something sensitive to talk about. In such countries, answering questions about emotional cut off is considered something socially rude. The latter result is consistent with the result concluded by Shehabihaghet al. (2018). The latter researchers suggest that the emotional cut off level among nurses is low in Iran. The employees in public hospitals enjoy higher job security levels. Their bonus system is fixed. Thus, the employees at public hospitals don't face much work pressure which may negatively marital relationship. Thus, they won't experience the phenomenon of (double income, no sex). The latter phenomenon was addressed by Olson \&Defrain (2003). Most of the respondents have a BA degree or a higher degree. That shall make the respondents address the marital daily life issues with more maturity to avoid negative implications. The respondents are concerned much in generating more income. Most of the respondents' family income is 1000 JDs or less $(74.8 \%)$. Such an income is considered low in comparison to the high cost of living.

This category shows a high self-efficacy level as it's suggested by Shehabihagh et al. (2018). Thus, the marital satisfaction of this category is high and the emotional cut off is low. The study shows that the relationship is a negative relationship.

When the level of hierarchy ambiguity is low, the likelihood of the anxiety to occur with a psychological and emotional load as a solution to imbalance is low.

Regarding the third questions, it sheds a light on hierarchy ambiguity and emotional cut off among the married female and male employees working at public hospitals. It was found that there isn't any significant relationship between hierarchy ambiguity and emotional cut off.

The hierarchy ambiguity in the marriage hierarchy is an indicator for the occurrence of marital disputes. Such disputes may lead to experiencing emotional cut off. Differentiation is highly linked with EQ and marital satisfaction (Javadi et al., 2015). High EQ level enables one to handle work pressures wisely, and clearly without experiencing hierarchy ambiguity. That shall increase the marital satisfaction and reduce the emotional cut off level.

Regarding the fourth question, it aims to explore the differences between the respondents' hierarchy ambiguity levels which can be attributed to (the duration of the marriage, family income, and academic). It was found that there isn't any difference between the respondents' hierarchy ambiguity levels which can be attributed to the duration of the marriage. That's because the spouses with high education are capable to overcome the issues related to the relationship boundaries and determining the one who shall take the decision, and the higher level of education qualified the spouses to deal with the outside interferences from friends and the extended family which represent a reciprocal reason for hierarchy ambiguity, especially at the first and middle age of the marriage.

There isn't any significant difference between the respondents' hierarchy ambiguity levels which can be attributed to (the family income). That may be attributed to the fact that all the respondents' spouses are employees. That makes the respondents' spouses accept the income received from healthcare employees in institutions in general and such employees in public institutions in particular. The respondents' spouses are aware about the laws and regulations of healthcare professions. That shall make the respondents' marital decisions balanced, logical and consistent with the family income. Having a working spouse shall reduce how dominant the spouse is. That shall make the spouses understand each other more. The husbands' income and the wives income are close to one another. That shall participate in achieving fairness and equality. It shall 
participate in reducing the extent of practicing dominance by the spouses.And reducing the predictable psychological and physical violence Thus, the marital relationship shall not be threatened.

The spouses' academic qualification are close to one another. Therefore, it's reasonable to have no differences between the respondents' hierarchy ambiguity levels which can be attributed to the academic qualifications. When the spouses' academic qualification are close to one another, they shall not experience a sense of inferiority. Thus, no one shall none of the spouse shall indirectly influence the decision making process made by the other in order to do what he/she desires without making the spouse feel less powerful. When the spouses' academic qualification are close to one another, none of them will need to use power to make the decision by himself/herself nor use strategies to resolve daily issues and marital disputes.

There is a significant difference between the respondents' emotional cut off levels which can be attributed to the marriage duration for the favor of the ones who have been married for a period that exceeds 5 years. That's because life is full of happiness during the beginning of the marital life. During this period, both spouses shall perceive each other in a positive manner. Such perception shall make them overcome any issue that may negatively affect their marital life (Walsh, 2006). Today, most of the married people, especially the educated married ones seek adopting a birth planning approach. That's because Jordan is experiencing a bad economic status. It's because many women today are working. It's because children are not treated properly at nurseries. To adopt a birth planning approach, women take birth control pills during the first and the second years of marriage. That's done in order for the spouses to get to know to each other. Thus, the first five years of marriage today are different that the counterpart years in the past in Jordan. In the part, women used to seek giving birth to the greatest number of male children. That's done to meet social demands and avoid feeling insecurity about their feminine identity. Thus, during the first five years of marriage, spouses aren't facing children-related pressures. However, after many years, the spouses will have children. Thus, daily life responsibilities will be maximized. In addition, the spouses will have to take care of their parents, because they have become older. That shall make life full of pressures. Thus, harmony between the spouses will disappear. That shall increase the probabilities of experiencing emotional cut off. The same is suggested through Hilly's theory. The latter theory suggests that family goes through a cycle and transformations which vary from one family to another based on the marriage duration and the presence of songs/daughters.

It was found that there isn't any statistically significant difference between the respondents' emotional cut off levels which can be attributed to family income. That's because the employees in the public sector in Jordan realize the amount of income in this sector. Such employees realize that one exerts much effort to be hired in the public sector in order to enjoy high job security level. It's inconsistent with what's suggested by Katyal (2017). The latter researcher suggests that employees in public hospitals have high probabilities of experiencing emotional and psychological problems. That may be attributed to the nature of the work environment at the latter hospitals. The ones who work in the public sector in Jordan enjoy a high job security level and the vacation system is better than the counterpart system of the private sector.

It was found that there isn't any statistically significant difference between the respondents' emotional cut off levels which can be attributed to academic qualifications. That's because the husbands' academic qualifications are similar to the wives' academic qualifications. $74.8 \%$ of females have BA degree or higher and $69.7 \%$ of males have a BA degree or higher. Education plays a significant role in achieving intellectual and emotional harmony between the spouses. Reducing the likelihood of the violence .It also plays a significant role in letting the spouses avoid emotional cut off and separation.

\section{Conclusion}

It was found that the respondents' hierarchy ambiguity and emotional cut off levels are low. The low emotional cut off level of respondents may be attributed to the bad economic situation experienced by Jordan. It may be attributed to the low average income in Jordan. Such bad financial situations shall lead to experiencing marital problems and tensions. Such problems and tensions shall lead eventually to experiencing emotional cut off. After many years of experiencing emotional cut off, the spouses may emotionally separate or get divorced.

The low emotional cut off level of respondents may be attributed to the nature of the Jordanian culture. For instance, in such a culture, it's difficult for women to ask for divorced. In addition, in such a culture, divorced women face many difficulties. Therefore, many Jordanian women shall not ask for divorce and thus, they shall experience emotional cut off level.

It was found that there is a positive statistically significant relationship between emotional cut off from one hand and taking the marital decision and the marital influence from another hand. That was concluded among the 
married female and male employees working at public hospitals in Amman. It was found that there isn't any significant relationship between hierarchy ambiguity and emotional cut off.

It was found that there isn't any statistically significant difference in the respondents' hierarchy ambiguity and emotional cut off which can be attributed to the marriage duration, family income and academic qualifications. It was found that there is a significant difference between the respondents' emotional cut off levels which can be attributed to the marriage duration for the favor of the ones who have been married for a period that exceeds 5 years.

The researchers recommend conducting longitude studies that target the employees in public and private institutions. Such studies must explore the stages that spouses go through and the way spouses communicate with one another. They must explore whether there are differences between spouses that can be attributed to the marriage duration.

Most of the previous studies target employees in public institutions, housewives, and patients in clinics. The researchers recommend exploring marital-related factors that affect the communication between the spouses. Due to the low emotional cut off level of respondents, the researcher believes that measures must be taken by the government and social institutions for promoting knowledge among spouses about the way of maintaining a healthy relationship. The researcher also believes that measures must be taken and policies must be set to improve the financial status of the Jordanian family. That shall lead to promoting harmony and positive feelings among the members of the Jordanian family.

\section{References:}

Javadi, B. et al. (2105), a study of the relationship of self-differentiation and emotional intelligence with marital satisfaction of married women in Tehran (electronic version). Indian Journal of Positive Psychology. 6(2), 149-154.

Kaleta, K. (2014), Marital Satisfaction, Differentiation of Self and Stress Perceived by Women (electronic version). Polskie Forum Psychologize, 19(3), 305-319.

Elbarazi, I. \&Loney, T. \& Yousef, S. and Elias, A. (2017), Prevalence of Factor Associated with Burnout among Health Care Professionals in Arab Countries: A Systematic Review. BMC Health Service Research. 17: 491, DOI 10.1186/s12913-017-2319-8

Madanes, C. (1981), Strategic Family Therapy. California: Jossy-Bass Publishers.235-246.

AbdulAzeez E. P., \&Ghasidas, G (2013). Employed Women and Marital Satisfaction: A Study among Female Nurses (electronic Version). International Journal of Management and Social Sciences Research, 2(11), 17-22.

Al- Braithen, Abed Al-Aziz (2008). Family counselling, Al-Shorouq Distribution and Publication House. Amman. Jordan.

Alshawashereh, O. and Abdel Rahman, H. (2018). Emotional Separation and its Relationship with Irrational thinking Among Married People. The Jordanian Journal of Educational Sciences. 14(3).

Al-Shwashreh, Omar and Abed Al-Rahman, Heba (2018). Emotional separation and its ideas with the irrational thoughts among married people. The Jordanian Journal for Educational Sciences. 14(3). 301-313

Al-Udwan, Fatmeh and Al-Najar, Asma' (2016) Family counselling. Amman. Al-Maseerah Distribution and Publication House

Bazant, R. (2009). Behavior outcomes of young adults who were in alternative family placement and young adults who were not in alternative family placement as measured with a differentiation scale. Doctoral Dissertation. Alliant International University. San Diego.

Berg-Cross, L. (2001), Couples Therapy. ( $\left.2^{\text {nd }} e d\right)$. New York: The Haworth Clinical Practice Press.

Bokek-Cohen, Y. (2011), marital power bases as predictors of spousal influence strategies in a vacation purchase decision (electronic version). International Journal of Culture. Tourism and Hospitality Research, 5 (2), 144-157.

Bowen, M. (1978), Family therapy in clinical practice. New York: J. Aronson

Chuang C, Tseng P, Lin C, Lin K, Chen Y. (2016), Burnout in the intensive care unit professionals: A systematic review (electronic Version). Medicine (Baltimore) 95: e5629. https://doi.org/10.1097/MD.0000000000005629 PMID: 27977605

Dekkers, T. (2007), The Relationship of Decision Making and Division of Household Labor to relationship Satisfaction. Unpublished Master Thesis. LowaDtaye University, Ames, Lowa. Development and initial validation. Journal of Counseling Psychology, 56, 597 Doi:10.14656/PFP20140302.

Fenell, D. (2012), Counseling Families: An Introduction to Marriage, Couple, and Family Therapy, Colorado: Love Publishing Company.

Frye, N\&Karney, B. (2006). The context of aggressive behavior in marriage: A Longitudinal study of newlyweds. Journal of family psychology, 20(1), 12-20.

Glagging, S. (2002), Family Therapy: History, Theory, and Practice, ( $3^{\text {rd }}$ ed). Columbus/Ohio: Merrill Prentice Hall. 
Gurman, A. and Kniskern, D. (1981), Handbook of Family Therapy, New York: Brunner/Mazel Inc.

Haley, J. (1977), Problem-Solving Therapy New Strategies for Effective Family Therapy, San Francisco: Jossey-Bass Publisher.

Hayes, M. (1979). Strengthening Marriage in the middle years. In N stinnett, B. Chesser, \& J. Defrain(EDS), Building Family Strengths: Blueprints for action(pp. 387-389). Lincoln: University of Nebraska Press.

Jafarizadeh, M. and Afrasiabi, F. (2015). Study of the Relationship between Personal Factors and Emotional Divorce. Mediterranean Journal of Social Sciences. 6(6). 406-411

Katyal S. (2013), Burnout among Nurses Working in Government and Private Hospitals. Studies on Home and Community Science. 7(2):83-5. https://doi.org/10.1080/09737189.2013.11885396

Kerr, M. E., \& Bowen, M. (1988). Family evaluation: An approach based on Bowen theory. New York: W. W. Norton.

Kincaid, S. and Caldwell, R. (2008). Marital separation. Journal of divorce and remarriage. 22 (3)

Lawless H.T., and Heymann H. (1999) Descriptive Analysis. In: Sensory Evaluation of Food. Food science text series. Springer, Boston, MA

Nichols, W. and Everett, C. (1986), Systemic Family Therapy, New York: The Guilford Press.

Olson, D. and Defrain, J. (2000), Marriage and the Family: diversity and strengths, (3 ${ }^{\text {rd }}$ ed). Mountain view calif: Myfield

Platt, L. (2008), the Family Genogram Interview: Reliability and Validity of a New Interview Protocol. Unpublished Doctoral Dissertation, the Pennsylvania State University, Pennsylvania.

Ramu, G. (1988), Marital Role Power: Perceptions and Reality in the Urban Setting. Journal of Comparative Family Studies, 19(2), 207-227.

References written in Arabic language

Rodman, H. (1972), Marital Power the Theory of Resources in Cultural Context. Journal of Comparative Family Studies, 3(1), 50-69.

Sahaf, K. (2015). Marital adjustment and its relationship by family stability among a sample of married couples in Makkah. Published MA thesis. Um Al-Quran University. Saudi Arabia.

Sahebihagh, M. \&Khorshidi, Z. \&Atri, S and Jafarabadi, M. (2017), Investigating the relationship between self-efficacy and emotional divorce among nurses in the city of Rasht Iran (2015). Annals of Tropical Medicine and Public Health, 10(6), 1596-1600.

Skowron, E. A., \& Friedlander, M. L. (1998). The differentiation of self inventory: Development and initial validation. Journal of Counseling Psychology, 45(3),

Smith, P \&Smith, R (2006), Family Counseling and Therapy, (Translated by FahedAldulaim), Saudi Arabia: King Souod University.

Solivar, G. (2003), Introduction to Family Theories. In: Sholevar,G. P and Schwoeri, L, D (ed), Family and Couples Therapy. American Psychiatric Publishing: Inc USA.

Story, L\&Repetti, R.(2006). Daily Occupational Stressors and Marital Behavior. Journal of Family Psychology, 20(4), 690700.

The Guilford Press.

Titelman, P. (2003), The Continuum of Emotional Cutoff in Divorce: An overview. In P. Titelman (Ed.) Emotional cutoff: Bowen family systems theory perspectives. New York: Haworth Clinical Practice Press.

Walsh, F. (2006), Strengthening Family Resilience, (2 ${ }^{\text {nd }}$ ed). New York:

Webster, C. (1998), the Meaning and Measurement of Marital Power: a Review Advanced in Consumer Research. 25, 395399.

Wechler, Joseph (2003), Structural Family Therapy. In: Hecher, Wechler(ed), An Introduction to Marriage and Family Therapy. (p.p 63-93), New York: The Haworth Clinical Practice Press.

Weiss, R. (1976). The emotional impact of marital separation. Journal of Social Issues. 32(1)

\section{Acknowledgment:}

The researcher would like to thank the participants in the study fortheir cooperationand assistance in conducting the present study. 